\title{
PODRÓŻ NA SYBERIĘ W ŚWIETLE WSPOMNIEŃ FLORIANA BOHDANOWICZA*
}

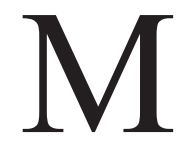

ało znane w historiografii polskiej wspomnienia Florian Bohdanowicza (Bogdanowicza) z pobytu na Syberii są znakomitym źródłem do analizy warunków bytowych polskich zesłańców przełomu lat 70 . i 80. XIX w., panujących w tym środowisku relacji społecznych, stosunku do polskich zesłańców miejscowej ludności oraz carskich urzędników. Zamieszczony we wspomnieniach szczegółowy opis podróży na zesłanie stanowi z kolei ciekawy i wydaje się reprezentatywny dla przełomu lat 70. i 80. XIX w. przykład długiej, uciążliwej i niezwykle bogatej we wrażenia i doznania osobiste peregrynacji polskich zesłańców.

O samym autorze wspomnień, poza szczegółowo opisanym przez Bohdanowicza we wspomnieniach pięcioletnim okresie pobytu na Syberii, niewiele wiadomo. Wspierając się krótką i zawierającą niestety wiele błędów notką, zamieszczoną w Słowniku Biograficznym Działaczy Rewolucyjnych ${ }^{1}$ dowiadujemy się, że Florian Bohdanowicz, syn Jerzego (niektórzy podają Grzegorza), urodził się ok. 1845 r. w zaborze austriackim. Ze wspomnień samego autora wynika natomiast, że miejscem jego urodzenia było Królestwo Polskie ${ }^{2}$. Jeśli przyjąć tą pierwszą wersje, to zapewne w wieku dziecięcym Florian przeniósł się z rodzicami do Królestwa Polskiego, gdzie pobierał nauki w gimnazjum warszawskim. Tu jako gimnazjalista - a w świetle wspomnień już student Szkoły Głównej ${ }^{3}$, brał udział $\mathrm{w}$ powstaniu styczniowym i prawdopodobnie pragnąc ustrzec się przed represjami opuścił Królestwo i udał się do Galicji, a następnie wyemigrował do

* Tekst powstał w ramach realizacji projektu NPRH: „Polscy zesłańcy na Syberii Zachodniej w drugiej połowie XVIII - XIX wieku w oczach Rosjan i ludności syberyjskiej (Umowa nr 0098/ NPRH3/H12/82/2014).

${ }^{1}$ Zob. Деятели революиионного движения в России. Био-библиографическии словарь от предшественников декабристов до падении ичаризма, red. Ф. Кон, А.А. Шилов Б.П. Козьмин, В.И. Невский, т. 2, Семидесятые годы, вып. 1, Москва 1929, s. 127.

2 Ф. Богданович, Воспоминания узника (1876-1885), Российский государственный архив социально-политической истории, Фонд 70, опис 50, дело 67, л. 148; F. Bohdanowicz, Wspomnienia więźnia (1876-1885), Lwów 1888, s. 132.

${ }^{3}$ F. Bohdanowicz, Wspomnienia więźnia..., s. 33. 
Szwajcarii. W Zurichu Bohdanowicz podjął studia na politechnice. Nawiązał tu liczne przyjaźnie z rosyjskimi i ukraińskimi działaczami rewolucyjnymi. Brał m.in. udział w próbie uwolnienia Sergiusza Nieczajewa - autora Katechizmu rewolucjonisty, który 14 sierpnia 1874 r. został zatrzymany i wydany w ręce carskiej policji po denuncjacji Adolfa Stempkowskiego - szpiega-prowokatora na usługach rządu rosyjskiego. Nieudana akcja uwolnienia, w której uczestniczył Bohdanowicz, miała miejsce październiku 1872 r. na dworcu w Zurichu, z którego Nieczajewa wysłano ostatecznie do Rosji.

Po zakończeniu studiów Bohdanowicz wrócił do Galicji, gdzie zaangażował się w działalność rewolucyjną, organizując m.in. przesyłanie nielegalnych wydawnictw zagranicznych do Rosji. W 1876 r. otrzymał propozycję podjęcia pracy, jako chemik w jednej z cukrowni w guberni kijowskiej. W tym celu opuścił 10 września 1876 r. Galicję lecz wkrótce po przekroczeniu granicy został aresztowany przez rosyjską żandarmerię i przez kilka miesięcy przetrzymywany w więzieniu kijowskim oraz w zakładzie psychiatrycznym. Przedmiotem dochodzenia stała się znaleziona przy nim kompromitująca go korespondencja oraz nielegalna literatura. Uwolniony za kaucją, został w maju 1878 r. po raz drugi aresztowany pod zarzutem rozpowszechniania literatury rewolucyjnej oraz posiadania materiałów wybuchowych. Osadzony ponownie w kijowskim więzieniu prawie rok oczekiwał na proces działaczy rewolucyjnych. Na mocy wyroku wydanego przez Sąd Kijowskiego Okręgu Wojskowego został w lipcu 1879 r. skazany za przynależność do organizacji rewolucyjnej na pozbawienie praw i 6 lat katorgi ${ }^{4}$. Jego podróż przez Syberię do miejsca przeznaczenia, jakim były kopalnie złota nad rzeką Karą, trwała blisko osiem miesięcy. Po trzech latach pobytu nad Karą przeniesiono go w 1883 r. do guberni jakuckiej, skąd ostatecznie po odbyciu 6-letniej kary zesłania, jako poddany monarchii habsburskiej, został w 1885 r. wydalony z Rosji. Zamieszkał we Lwowie, gdzie też zmarł 14 czerwca 1894 r.

$$
* * *
$$

Bohdanowicz opublikował kilka prac dotyczących pobytu na zesłaniu, które prawie całkowicie są nieznane. Interesujące nas dzieło było wydane dwukrotnie we Lwowie - po raz pierwszy w $1886 \mathrm{r}$. w okrojonej formie pt. $Z$ pamiętników więźnia stanu lat ostatnich (stron 67, nakładem „Przyjaciela Domowego”) oraz dwa lata później w wersji rozszerzonej pt. Wspomnienia więźnia (1876-1885), ss. 461. Drugą rozszerzoną wersję planowano także w okresie międzywojennym wydać w Rosji, o czym świadczą zachowane w tłumaczeniu na język rosyjskich rękopisy wspomnień Bohdanowicza przechowywane w archiwach petersburskim i moskiewskim 5 .

${ }^{4}$ F. Bohdanowicz, Wspomnienia więźnia..., s. 134.

5 Zob. Российский государственный архив социально-политической истории, Фонд 70, опис 50, дело 67, л. 1-343; Российский государственный исторический архив, Фонд 1903, опис 1, дело 3 , л. 1-227. 
1. Strona tytułowa trzeciego wydania J. Kennana „Syberia” (Lwów 1891) w przekładzie Floriana Bohdanowicza
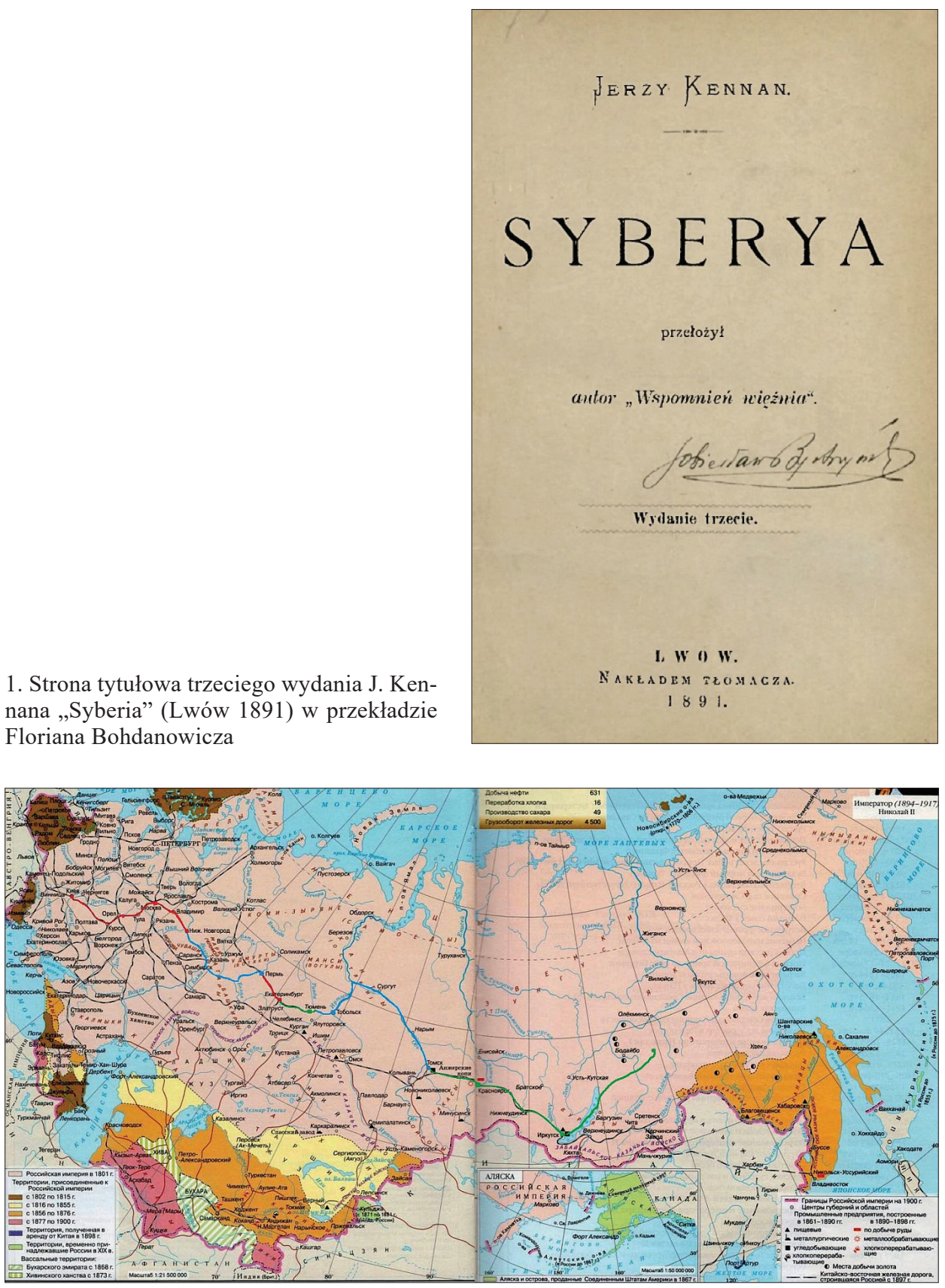

2. Trasa podróży F. Bohdanowicza z Kijowa do Kary (kolor czerwony - droga kolejowa; niebieski - szlak wodny; zielony - trakt lądowy) 
Bohdanowicz opublikował także na przełomie 1890/1891 r. pod pseudonimem Autor „Wspomnień więźnia” pracę pt. Wygnania i męczeństwo polskich patriotów. Nie wiemy jednak, czy ta praca wyszła jako osobna publikacja ${ }^{6}$. Największy rozgłos i uznanie przyniosło jednak Bogdanowiczowi tłumaczenie i pięciokrotne wydanie zakazanej w Rosji i w Królestwie Polskim książki Georga Kennana pt. Syberia. Wszystkie te wydania oparzone anonimową adnotacją: »Przełożył autor „Wspomnień więźnia”" ukazały się we Lwowie. Pierwsze, wydane nakładem własnym w 1890 r., drugie w 1891 r., trzecie, już po śmierci, w 1895 r., a czwarte w 1896 r. Warto nadmienić, że kolejne piąte wydanie pracy Kennana (Warszawa 1907) z przedmową Zdzisława Dębickiego było już thumaczenia Karola Łaganowskiego (1856-1917).

$$
* * *
$$

Bohdanowicz, jak większość zesłańców, swoją podróż na Syberię rozpoczynał z miejsca czasowego przetrzymywania, to jest $\mathrm{z}$ więzienia. W przypadku Bohdanowicza było to więzienie w Kijowie, gdzie przetrzymywano go jako oskarżonego o udział w ruchu rewolucyjno-socjalistycznym oraz przygotowanie akcji terrorystycznych - proces tzw. grupy Józefa Bilczańskiego ${ }^{7}$. Po ogłoszeniu wyroku Sądu Kijowskiego Okręgu Wojennego Bohdanowicz wraz ze swoimi współtowarzyszami: Zaubrzyckim i Krasowskim, Bogrynowskim, Predtieszyńskim, Kozakiewiczem, Krechstowiczem ${ }^{8}$, Dawidienką ${ }^{9}$, Zandströmem i Czajkowem, rozpoczął 26 lipca 1879 r. podróż z Kijowa do kopalń złota leżących w Obwodzie Zabajkalskim nad rzeką Karą ${ }^{10}$. Jeszcze przed wyruszeniem z Kijowa był świadkiem

${ }^{6}$ Zob. Bibliografia Polska XIX wieku, pod red. K. Estreichera, t. 2, wyd. 2, Kraków 1961, s. 412.

7 Osip N. Bilczański (1858-1879) - pseudonim „Gorbaczow”, syn oficera policji, z wykształcenia ślusarz. Należał do kółka rewolucyjnego założonego w Żytomierzu pod przywództwem studenta Basowa. Aresztowany i więziony w Kijowie, oskarżony o udział w napadzie na karetę pocztową kursującą na linii Żytomierz - Kijów i zabójstwo Tarasa Kuriłowa, powieszony 14 VII 1879 r. Zob. „Народная воля” 1879, nr 1; A.J. Gobst; P.G. Górski - należał do żytomierskiej grypy rewolucjonistów.

${ }^{8}$ F. Bohdanowicz błędnie podaje nazwisko. Właściwie mowa o I. Kreczetowiczu, który należał do żytomierskiej grypy rewolucjonistów.

${ }^{9}$ Filip Jakowlewicz Dawidienko (1860-1928) skazany w procesie Bilczańskiego i Górskiego na 20 lat katorgi, ułaskawiony na 12 . Za przygotowanie paszportu dla uciekiniera z Irkuckiego więzienia w styczniu 1880 r. dodano mu trzy lata katorgi. Przybył do Kary w marcu 1880 r., w 1893 r. osiedlony w okręgu jakuckim. Zamieszkiwał w Namsku i Bogorodsku, następnie w Jakucku, gdzie został zatrudniony w miejscowym muzeum. Pod koniec lat 90. XIX w. przeniósł się do Czyty, a potem do Irkucka. Tu zmarł w $1928 \mathrm{r}$.

10 Российский государственный исторический архив, Фонд 1903, опис 1, дело 3, л. 147; Kara (Czarna) - niewielka rzeka w Obwodzie Zabajkalskim, w pobliżu której ok. 1820 r. odkryto złoża złota. Od 1873 r. do Kary zsyłano przestępców politycznych. Ogółem do Kary zesłano 217 zesłańców politycznych (185 mężczyzn i 32 kobiety). Kara była miejscem licznych buntów i protestów zesłańców (głodówek, samobójstw), co przyczyniło się do zelżenia obowiązującego tu regulaminu. W 1892 r. zaprzestano zsyłek do Kary likwidując obóz pracy, co po części wiązało się z wyczerpaniem złóż złota. 
egzekucji skazanych na karę śmierci trzech współtowarzyszy: Hobsta, Bilczańskiego i Górskiego - wyrok wykonano 14 lipca 1879 r. ${ }^{11}$. Samą podróż poprzedził rozkaz naczelnika kijowskiego więzienia, który nakazał skonfiskowanie zesłańcom odzieży i książek oraz ciepłej bielizny aresztanckiej. W zamian wydano im zgrzebną odzież. Jak twierdził Bohdanowicz „był to prawdziwie piekielny wynalazek, gdyż ostre paździerze wpijając się w ciało sprawiały niewypowiedziane bóle"l2.

Bohdanowicz pierwszy etap podróży na Syberię odbył, w przeciwieństwie do wielu wcześniejszych pokoleń zesłańców, koleją. Było to możliwe za sprawą otwartego w 1870 r. połączenia kolejowego między Kijowem a Moskwą. Tu warto przypomnieć, że Moskwa, poza Petersburgiem stanowiła jeden z najważniejszych punktów etapowych w europejskiej części Cesarstwa Rosyjskiego, w którym przeprowadzano jedną z pierwszych weryfikacji zesłańców odprawianych $\mathrm{w}$ dalszą drogę. $\mathrm{Z}$ więzienia kijowskiego aresztantów wywieziono dwiema wielkimi karetami pod eskortą półtorej sotni dońskich kozaków. Mimo tak silnej eskorty władze policyjne, nie odważyły się dostarczyć więźniów na kijowski dworzec kolejowy drogą prostą przez miasto. Być może obawiano się podejmowanych już wcześniej prób odbicia więźniów, lub też starano się skrzętnie ukryć przed społeczeństwem sposoby transportowania skazańców. Bohdanowicza wraz z innymi wieziono zatem bocznymi ulicami, najpierw do położonej za miastem warowni, a następnie polnymi drogami do oddalonego poza miastem punktu przy linii kolejowej, w którym pomiędzy budkami strażniczymi czekała na zesłańców lokomotywa z jednym wagonem pilnowanym przez policyjną eskortę. Dopiero stąd wagon wypełniony więźniami podciągnięto na stację kolejową do Kijowa i ukradkiem przyczepiono do składu pociągu osobowego.

Po całodobowej podróży wagon z więźniami dotarł wieczorem 27 lipca 1879 r. do Mceńska - miasteczka położonego w guberni orłowskiej. Tu zesłańcom nakazano przesiadkę do podstawionych kibitek, którymi przewieziono ich do miejscowego więzienia położonego wśród pól i lasów z dala od miasta. Więzienie w Mceńsku, jak można zorientować się ze wspomnień Bohdanowicza, przejęło na siebie rolę moskiewskiego punktu wstępnej weryfikacji i dalszej deportacji zesłańców. Ponadto, jak pisał Bogdanowicz,

tutaj zamorzeni i wymęczeni więźniowie w tak zwanych centralkach znachodzili [znajdowali - S.W.] jaką taką pomoc lekarską a przede wszystkim nieco swobody, a także i lepszą strawę $e^{13}$.

${ }^{11}$ Wyrokiem sądu na karę śmierci skazano pięciu działaczy, przy czym Zaubrzyckiemu i Krasowskiemu na mocy aktu łaski generała-gubernatora w ostatniej chwili zamieniono karę śmierci na zesłanie.

12 Российский государственный исторический архив, Фонд 1903, опис 1, дело 3, л. 148.

13 Tamże; F. Bohdanowicz, Wspomnienia więźnia..., s. 143. 
W porównaniu z warunkami panującymi w innych więzieniach carskiej Rosji, zarówno tych na Syberii, jak i znanego już Bohdanowiczowi więzienia w Kijowie, "centralka" (więzienie) w Mceńsku była jednym z najbardziej przyjaznych i wygodnych dla zesłańców.

Izba w której nas pomieszczono - wspominał Bohdanowicz - była obszerną, schludną i zaopatrzoną odpowiednią dla liczby więźniów ilością zasłanych czystą pościelą łóżek. Rządca więźniów, człowiek delikatny w obejściu, oswobodził nas na dzień z pod zamka, nastręczając nam sposobność do złączenia się w jedno towarzystwo z zamieszkującymi tu czasowo wygnańcami odeskimi ${ }^{14}$. [...] Zastaliśmy tutaj kilkadziesiąt osób wysłanych samowolnie [w trybie administracyjnym - S.W.] na Sybir z rozporządzenia tyranów odeskich [Edwarda] Todlebena i [Stiepana] Paniutina ${ }^{15}$.

W Mceńsku Bohdanowicz miał także okazję zawrzeć znajomość z przywiezionymi tu w tym samym czasie pięcioma ,więźniami stanu z Charkowa: gimnazjalistą Jacewiczem, majtkiem floty czarnomorskiej Bereźniakiem oraz robotnikami Rodinem, Raszko i Pytajewem".

Po pięciodniowym wypoczynku w Mceńsku Bohdanowicz 3 sierpnia $1879 \mathrm{r}$. został drogą powrotną odstawiony kibitką do stacji kolejowej, by następnie po całym dniu jazdy w wagonie aresztanckim, rankiem zatrzymać się w Moskwie. Tu, jak wspominał, jego oczom „ukazały się wydobywające się z pośród gęstej mgły wierzchołki kopuł cerkwi kremlińskich”. Ponieważ następnym punktem dyslokacji dla więźniów miał być Niżny Nowogród, z którym od 1862 r. Moskwa miała połączenie kolejowe, stąd też więźniom nie dano możliwości dłuższego pobytu w historycznej stolicy Rosji.

Na dworcu moskiewskim - zanotował Bohdanowicz - nie wypuszczono nas na platformę, zmieniono tylko żandarmów i ruszyliśmy dalej. Nowy oficer, jakiś osowiały formalista nie przestawał przypominać żandarmom, by więźniów mieli na oku i nie dopuszczali ich do okien wagonu ${ }^{16}$.

Do Niżnego Nowogrodu - miasta znanego ze słynnych jarmarków, Bohdanowicz dotarł dnia następnego przed południem, czyli 5 sierpnia 1879 r. Był to ostatni punkt tej części podróży, która przebiegła stosunkowo szybko, a to za sprawą możliwego w tym czasie do wykorzystania transportu kolejowego. Ten pierwszy etap podróży, wliczając w to pięciodniowy pobyt w Mceńsku, trwał zaledwie 11 dni, a po jego zakończeniu rozpoczynała się podróż szlakiem wodnym.

${ }^{14}$ Grupa zesłańców odeskich, według Bohdanowicza, liczyła 17 osób. Byli to literaci: Jużakow, Riabkow, Winogradzki, Awdijew, Panfiłow; studenci: Żołtanowski, Lion, Spandoni, Mirolubow, Dziubiński; urzędnicy: Czandowski, Malowany, Kowalewski, Popow; rzemieślnicy: Radecki, Wsiewołowski oraz weterynarz dońskich kozaków - Sokownin.

15 Российский государственный исторический архив, Фонд 1903, опис 1, дело 3, л. 148.

${ }^{16}$ F. Bohdanowicz, Wspomnienia więźnia..., s. 146. 
Po przybyciu do Niżnego Nowogrodu Bohdanowicz wraz z towarzyszami, został odtransportowany na przystań nad rzekę Okę. Tu więźniów przerzucono do specjalnie przygotowanej na ten cel barki, przyczepionej linami do parostatku. $\mathrm{Na}$ barce zesłańcy krótkim odcinkiem, wraz z biegiem Oki, dopłynęli do Wołgi, a następnie z nurtem rzeki, mijając Kazań, dotarli do ujścia rzeki Kamy, by z kolei płynąc najtrudniejszym odcinkiem pod prąd rzeki Kamy dostać się do Permu. Warunki transportu szlakiem wodnym z Niżnego Nowogrodu do Permu były dla zesłańców dość uciążliwe.

W ciągu całej tej sześciodniowej podróży - wspominał Bohdanowicz - zamknięci byliśmy wszyscy w posępnej kajucie przyczepionej do parostatku barki. Wypuszczono nas tylko raz na dobę na pokład ogrodzony wokoło wysoką żelazną siatką, zza której wyglądaliśmy jak prawdziwe zwierzęta.

$\mathrm{Na}$ jednej z przystani rzecznych na Wołdze do grona zesłańców dołączył młody literat [?] Borodin, który przekazał Bohdanowiczowi wieści o losach polskiego wygnańca Oskara Awejde.

Od niego - pisał Bohdanowicz - dowiedziałem się, że Awejde, były sekretarz Rządu Narodowego, cieszył się w Wiatce sławą najzdolniejszego adwokata, a przy tym i najlepszym bytem materialnym ${ }^{17}$.

Niezwłocznie po przypłynięciu 13 sierpnia nocą do Permu leżącego u stóp gór Ural, zesłańcy po krótkim odpoczynku zostali w godzinach popołudniowych odwiezieni na stację kolejową i ruszyli ponownie drogą żelazną w kierunku Jekaterynburga. Warto $\mathrm{w}$ tym miejscu przypomnieć, że transport ten był możliwy zaledwie od dwóch lat, gdyż kolejowe połączenie z Permu do Jekaterynburga uruchomiono w 1877 r. wraz z oddaniem do użytku Uralskiej Drogi Żelaznej stanowiącej jeden z pierwszych odcinków późniejszej kolei transsyberyjskiej. Nowe połączenie komunikacyjne sprawiło, że w odróżnieniu od wielu innych polskich zesłańców Bohdanowiczowi przyszło, jako jednemu z pierwszych, przekroczyć granice kontynentów z pozycji zesłańca transportowanego koleją żelazną.

Linia kolei żelaznej licząca 400 wiorst - notował Bohdanowicz - snuje się po tak posępnej i jałowej okolicy, że zdaje się nie ma człowieka na którego widoki te nie oddziaływałyby przygnębiająco. [...] W tej osieroconej z wszelkiego powabu okolicy napotykają się między innymi dwie stacje kolei żelaznej, z której jedna nosi na sobie napis Europa, druga zaś Azja. Ta ostatnia nazwa przypominająca dotykalnie każdemu z nas jego obecność w drugiej części świata, gdzie prawdopodobnie złoży kości swoje, duszę nam przysłoniła kirem smutku i tęsknoty ${ }^{18}$.

17 Tamże, s. 149.

18 Российский государственный архив социально-политической истории, Фонд 70, опис 50, дело 67, л. 101. 
Gdyby Bohdanowicz odbywał podróż na Syberię rok później, zapewne mógłby skorzystać z kolejnego udogodnienia, jakim było przedłużenie Kolei Uralskiej o kolejny odcinek, łączący od 1880 r. Jekaterynburg z Tiumeniem. Niestety droga kolejowa do Tiumenia była jeszcze na etapie budowy, dlatego też po przybyciu wieczorem do Jekaterynburga, Bohdanowicza wraz z kolegami powieziono bezzwłocznie z dworca kolei na kibitkach do Tiumenia. Jak zanotował autor wspomnień „tę 306 wiorstową odległość przebyliśmy w niespełna 30 godzin”, co oznaczało, że średnia prędkość z jaką pędziły kibitki była jak na warunki syberyjskie stosunkowo duża, gdyż nie licząc czasu postoju, wynosiła średnio dziesięć wiorst na godzinę.

Tiumeń okazał się kolejnym punktem weryfikacji zesłańców, którą przeprowadzała urzędująca w tym mieście komisja ekspedycyjna. Po sprawdzeniu tożsamość wszystkich osób, komisja skierowała zesłańców do miejscowego więzienia, które w ocenie Bohdanowicza należało do jednego z najgorszych w całej Syberii.

Trudno sobie wyobrazić niechlujstwo, z jakim spotkaliśmy się w więzieniu tiumeńskim - pisał Bohdanowicz. Ściany czerniały od pluskw, odór zabójczy, a ławy (mary) ten jedyny sprzęt naszego lokalu, pokryte były skorupami brudu. Niepodobieństwem było egzystować w takim położeniu. Toteż przyzwaliśmy wszystkie tameczne władze, upominając się od nich z całą natarczywością o zmianę lokalu. Nasze nalegania nie osiągnęły skutku, a jedynym ustępstwem jakiego dobiliśmy się, było pozwolenie palenia tytoniu, artykułu tak surowo wzbronionego w tamecznych więzieniach ${ }^{19}$.

W więzieniu tiumeńskim zesłańcy spędzili pięć dni. Następnego dnia odtransportowano ich na przystań, przy której cumował czekający już na nich parostatek. Dla Bohdanowicza rozpoczynał się w podróży na Syberię drugi, znacznie dłuższy etap szlakiem wodnym. Z Tiumenia rzekami Tura, Toboł, Irtysz i Ob zesłańców transportowano do Tomska. Tym razem na barkę przywiązaną do parostatku załadowano oprócz więźniów politycznych także przestępców kryminalnych.

Ogromna barka, w której na pomieszkanie przeznaczono nam dwie wcale schludne kajuty - wspominał Bohdanowicz - mieściła pod pokładem około 400 więźniów zwyczajnych. Mężczyźni, kobiety, dzieci wszystko to leżało pokotem na czerniącej od błota podłodze, a ciemność panująca tu wskutek maleńkich okien, przepuszczających zaledwie wiązkę światła słonecznego, nadawała całemu obrazowi cechę grobowej ponurości ${ }^{20}$.

Kajuta, w której ulokowano jedenastu więźniów politycznych pełniła równocześnie rolę gabinetu lekarskiego, otwieranego w godzinach dopołudniowych w celu przyjmowania chorych więźniów. Bohdanowicz będący mimowolnym świadkiem udzielanej pomocy lekarskiej, tak opisał stosunek do chorych oraz stosowane metody.

19 Tamże, л. 101-102.

${ }^{20}$ Tamże. 
Lekarz, jakiś młody Izraelita, nie dopuszczając pacjentów do słowa, ani też nie zajmując się badaniem ich, darzył każdego a priori kawałkiem aloesu, szczyptą mięty lub kubeczkiem oleju rycynowego.

Ci, którzy dopraszali się wysłuchania historii swojej choroby, byli z polecenia lekarza wypychani przez żołnierzy za drzwi.

Wielmożny panie! - wołali błagalnie wijący się w kurczowych bólach pacjenci. Zmiłuj się nad nami, każ nas z tego brudu i zgnilizny przenieść w suchsze miejsce, my wszyscy tam wyginiemy.

- A gdzie to wasze legowiska? - spytał eskulap.

- Przy samych wychodkach, nurzamy się w kałużach. Zmiłuj się - błagali nieszczęśliwi.

- Nie grzeszcie ludzie! Wszak wy skarżycie się na bole żołądków? Możesz więc być co dla was więcej pożądanego, jak mieć wychodki pod nosem - dowcipkował eskulap, głaskając swą ruda brodę ${ }^{21}$.

Przedłużająca się podróż rzekami Irtysz i Ob była dla Bohdanowicza także okazją do obserwowania mieszkających na wybrzeżach rzek plemion Ostiaków.

Lud ten - wspominał Bohdanowicz - nie zdradzający żadnych cech cywilizacji, należy do rasy mongolskiej. Przyodziewek jego stanowią skóry dzikich zwierząt, pokarm zaś wyłącznie mięso i ryba. Niejednokrotnie miałem sposobność oglądania ich, gdy na maleńkich czółnach podsuwali się pod statek z rybą na sprzedaż. Żołnierze, którym słabość Ostiaków do różnego rodzaju błyskotek była dobrze znaną, wyzyskiwali ich niemiłosiernie biorąc częstokroć w zamian za odłamek lusterka lub też czerwoną szmatkę, cetnary doborowej ryby $^{22}$.

Trudne warunki transportu, licha strawa, wilgotne powietrze w przeludnionych kajutach oraz dające się we znaki zesłańcom jesienna słota, niekorzystnie wpływały na stan zdrowia i były powodem dużej śmiertelności więźniów.

Dotychczas jeszcze stoi mi na oczach ponury obraz z jakim spotkałem się pewnego razu wśród nocy na pokładzie budki. Miesiąc wypływający z poza czarnych chmur gonionych jesiennym wichrem, obnażył sczerniałe zwłoki leżącego na deskach trupa. Głowa jego była w połowie ogoloną, okowy ciążyły na schudzonych piszczelach, a unoszące się nad pokładem drapieżne ptactwo, przeraźliwym krzykiem dopominało się o swą zdobycz.

- Dlaczego nie pozostawiliście go na przystani? Wszak umarły, spytałem stróżującego mnie żołnierza. - Podług przepisu należy go oddać władzom gubernialnym, odrzekł tenże. I rzeczywiście ulegający stopniowemu rozkładowi trup więźnia podróżował z nami aż do Tobolska, gdzie go pozostawiono na brzegu rzeki ${ }^{23}$.

${ }^{21}$ F. Bohdanowicz, Wspomnienia więźnia..., s. 151-152.

22 Российский государственный архив социально-политической истории, Фонд 70, опис 50, дело 67, л. 102.

${ }^{23}$ Tamże, л. 104. 
Po przypłynięciu do Tomska zesłańców ponownie zweryfikowała komisja odbiorcza w osobach radcy gubernialnego Parafinowicza oraz doktora Florenty Orzeszki ${ }^{24}$, ,byłego wygnańca za udział w powstaniu 63 r.”. Po dokonaniu kontroli wszystkich zesłańców odtransportowano do miejscowego więzienia. W więzieniu tomskim Bohdanowicz kilka dni gorączkował, gdy tymczasem jego towarzysze podróży ruszyli dalej w podróż do Krasnojarska. Dłuższy pobyt w Tomsku stał się dla Bohdanowicza okazją do lepszego poznania miejscowych warunków więziennych. $Z$ perspektywy kilku lat tak wspominał panujące tam zwyczaje:

Radcą więzienia był jakiś wysłużony stary oficer, [...] niezwykły pedant i formalista wzbraniał surowo służbie wypuszczać nas spod zamku. Rozkazy te nigdzie nie wypadały komiczniej dla wydającego je, jak tutaj. Cała służba więzienna składająca się z najemnych włóczęgów i pijanic gotowa była za kilkurublowy datek nie tylko otworzyć bramę więźniowi, ale nadto dzielić dolę zbiega. Nieład administracyjny doszedł tu do swego zenitu. Rządca wraz z swymi pomocnikami zajęci byli od ranka do nocy kontrolą więźniów, których liczba nigdy nie była dla nich wiadomą. To niepowodzenie arytmetyczne stawało się powodem do bezustannych wzajemnych sprzeczek kończących się nie tylko łajaniem, ale i policzkowaniem, a następnie całonocną pijatyką. Więźniowie kryminalni korzystając z nieporozumień pomiędzy władzami całymi bandami wychodzili sobie na miasto, skąd schwytanych na kradzieży i pijatyce policja miejska odstawiała napowrót do więzienia. Z przybyciem naszym ustała nawet kontrola przestępców kryminalnych; władze zagrożone surową odpowiedzialnością za całość liczby więźniów stanu, całą swą baczność zwracały wyłącznie na nich.

Pamiętajcie psy - wrzeszczał rządca więzienia do dozorców - że za wypuszczenie przestępcy stanu chociażby za próg celi oczekuje was chłosta i katorga. - Pogróżki te atoli były grochem rzucanym o ścianę, skoro tylko rządca wyszedł za bramę, nasz odźwierny otwierał natychmiast drzwi kazarmy oznajmiając że stary pies zalazł do budy ${ }^{25}$.

Podczas pobytu w więzieniu w Tomsku Bohdanowicz był także świadkiem przybycia do Tomska oddzielnej partii kobiet-więźniów.

W tym czasie - wspominał Bohdanowicz - do więzienia tomskiego odtransportowano do ciężkich robót i na osiedlenie 26 kobiet. Widok przybyłych ścisnął mi serce. Wszystkie one wycieńczone na siłach drżały z zimna i głodu. W liczbie ich było kilka matek z drobnemi dziećmi, dzielących dobrowolnie smutną dolę swych mężów i piętnastoletnia uczennica gimnazjum odeskiego Gułkowska ${ }^{26}$ skazana na wieczne wygnanie nad brzegi Oceanu

${ }^{24}$ Florenty Orzeszko (1833-1905) - lekarz, powstaniec. Za prowadzenie agitacji powstańczej w powiecie kobryńskim - w rejonie działalności oddziałów Romualda Traugutta, został skazany na zesłanie do Tomska, a jego majątek Owsicze skonfiskowany. W Tomsku, po zniesieniu nad nim dozoru policyjnego w 1871 r., zezwolono mu na prowadzenie praktyki lekarskiej, a wkrótce zatrudniono na stanowisku lekarza przy miejscowym więzieniu. Na zesłaniu zmarły mu trzy córki i 27-letnia żona. Przez całe życie związany był z więzieniem tomskim. Zob. I. Budnik, Florenty Orzeszko: lekarz i powstaniec, „Magazyn Polski” 2013, nr 1, s. 10-15.

${ }^{25}$ F. Bohdanowicz, Wspomnienia więźnia..., s. 155-156.

${ }^{26}$ Wspomniana Gułkowska, jak dodawał Bohdanowicz, niezadługo potem odebrała sobie życie w Krasnojarsku. 
Lodowatego do Turchańska. Z braku odpowiedniego lokalu przybyłe kobiety pomieszczono w naszej kazarmie, przenosząc nas do drugiej, zamieszkałej przez 200 przestępców kryminalnych ${ }^{27}$.

Przeniesienie do celi z więźniami kryminalnymi pozwoliło Bohdanowiczowi przyjrzeć się dokładniej warunkom życia tej grupy przestępców. Szczególnie w pamięci utkwiły mu zwyczaje prowadzonych w celach gier hazardowych, w których

monetą zdawkową były łyżeczki, filiżanki, bielizna, pasy, chałaty aresztanckie a nawet podarte obuwie, $[\ldots]$ zaś gra w karty szła nie tylko przy grubych łojówkach, ale także i przy cienkich jak drut szabasówkach ${ }^{28}$; w innych znów miejscach karty zastępowały całe baterie butelek śmierdzącej wódki.

Warto w tym miejscu przytoczyć krótką rozmowę, jaką Bohdanowicz przeprowadził z jednym z więźniów:

Co to znaczy? - spytałem tuż przy mnie stojącego więźnia ukazując na drżących od zimna ludzi.

- Zgrali się do ostatniej nitki - odpowiedział on obojętnie.

- Jakże będzie $\mathrm{z}$ ich odzieżą? - spytałem ponownie.

- Rządca więzienia - rzekł on z pewnym szyderstwem - każe ich ogrzać rózgami, a potem wydadzą im z magazynu inną odzież i obuwie ${ }^{29}$.

Zupełnie inaczej niż przestępcy kryminalni zachowywali się przebywający z nimi w celi Kozacy kubańscy, których, jak notował Bohdanowicz, ,śniadawe twarze o regularnych rysach, okolone bujnym czarnym zarostem, nosiły wyraz troski i głębokiej zadumy". W losach i postawach Kozaków kubańskich, którym rząd za stawianie czynnego oporu przy likwidacji kozackiej autonomii oraz samorządu i swobód kulturowych, odebrał ziemię, zniszczył dobytek a następnie zesłał na ciężkie roboty na Syberię - upatrywał Bohdanowicz wiele analogii do losów Polaków.

Przedłużający się pobyt $\mathrm{w}$ Tomsku oraz obcowanie $\mathrm{z}$ różnymi kategoriami przestępców i zesłańców pozwoliły Bohdanowiczowi dokonać ciekawych spostrzeżeń na temat lokalnych zwyczajów, jak też więziennej hierarchii.

Znajdując się w samym centrum więzienia - wspominał Bohdanowicz, a do tego będąc niezależnym, miałem wszelką sposobność przypatrzenia się na jak najbliższą metę korporacji aresztanckiej i jej obyczajom. Jak we wszystkich ludzkich społeczeństwach, tak też i tutaj wodziła rej arystokracja, składająca się z zamożnej inteligencji. Ludzie ci, na których

\footnotetext{
${ }^{27}$ F. Bohdanowicz, Wspomnienia więźnia..., s.. 158

${ }^{28}$ To jest tych miejscach w celach, w których gromadzili się przestępcy pochodzenia żydowskiego.

${ }^{29}$ F. Bohdanowicz, Wspomnienia więźnia..., s. 159-160.
} 
ciążyła przeważnie zbrodnia kradzieży wielkich sum pieniężnych, bądź to rządowych bądź prywatnych instytucji, używali powszechnego szacunku nie tylko w całym gronie aresztantów, ale nadto u zwierzchności więziennej ${ }^{30}$.

Odwołując się do przykładów potwierdzających te tezy Bohdanowicz przybliżył historię polskiego zesłańca - niejakiego „A-skiego”, spekulanta finansowego, zesłanego początkowo do guberni archangielskiej, a następnie za przestępstwo kryminalne, tj. zabójstwo służącego, na osiedlenie do Syberii Zachodniej, który wykorzystując swoją pozycję $\mathrm{w}$ hierarchii więziennej oraz znajdując uznanie w oczach lokalnej administracji potrafił owładnąc całą dyrekcją tomskiego więzienia ${ }^{31}$.

Po powrocie do zdrowia, w nocy ostatniego dnia września 1879 r., Bohdanowicz pod eskortą żandarmów został wysłany w dalszą podróż z Tomska do stolicy guberni jenisejskiej - Krasnojarska. Pierwszy odcinek tej podróży był utrudniony ze względu na przypadający akurat w tym samym czasie powrót odwołanego z urzędu generała-gubernatora Wschodniej Syberii, a ongiś naczelnika Warszawskiego Okręgu Żandarmerii - barona Płatona Fredericksa ${ }^{32}$, który do Petersburga „wracał z nabytą za $10000 \mathrm{rb}$. małżonką" ${ }^{33}$. Skrzyżowanie się szlaków podróży barona Frederiska z etapem wędrówki Floriana Bohdanowicza było o tyle kłopotliwe, że przez pewien czas nie można było liczyć na stacjach na znalezienie jakiegokolwiek przytułku oraz świeżych koni. Dodatkowo podróż utrudniała nieustanna słota, silne wiatry, jak też padający od Aczyńska i dokuczliwy dla zesłańców mokry śnieg.

W czasie podróży do Krasnojarska Bohdanowicz ze względu na warunki pogodowe przez kilka dni zmuszony był zatrzymać się na stacji pocztowej w Czarnej Rzeczce, którą kierował pocztmistrz - z pochodzenia Szwed.

Człowiek ten - wspominał Bohdanowicz, wcale sympatyczny przyjął mnie z otwartymi rękami. Będąc sam wygnańcem, nosił w sobie niekłamane uznanie i współczucie dla więźniów stanu. Odprowadzając mnie do bryczki pocztowej, podrzuciwszy w górę czapkę, krzyknął na całe gardło: »Es lebe die Freiheit! Verlieren Sie die Courage nicht «! [Niech żyje wolność! Nie traćcie odwagi! S.W.] ${ }^{34}$.

Kolejnym przystankiem w uciążliwej podróży etapami okazało się piąte w kolejności po kijowskim, mceńskim, tiumeńskim i tomskim więzienie w Krasnojarsku, którego naczelnikiem w tym czasie był Polak, niejaki Ostrowski.

30 Российский государственный исторический архив, Фонд 1903, опис 1, дело 3, л. 111.

31 Tamże.

${ }^{32}$ Zob. Sytuacja polityczna Królestwa Polskiego w świetle tajnych raportów naczelników Warszawskiego Okręgu Żandarmerii z lata 1867-1872 i 1878, oprac. S. Wiech, W. Caban, Kielce 1999, s. $37-38,79$.

${ }^{33}$ F. Bohdanowicz, Wspomnienia więźnia..., s. 165.

34 Tamże, s. 167. 
Po dopełnieniu formalności odbiorczych - pisał Bohdanowicz, rządca więzienia Polak Ostrowski poprowadził mnie do wnętrza budynku. Wstępowaliśmy na pierwsze schody, gdy niebawem mury więzienne zadrgały hymnem „Boże coś Polskę”. [...] Dziwne koleje losu. Pieśń ta prześladowana tak srodze przez Rosjan wyrywała się obecnie przeważnie z ich własnych piersi. Między więźniami tutejszymi, których liczba dochodziła do stu, spotkałem i towarzyszów mojej podróży. Straciwszy nadzieje w moje uzdrowienie, witali mnie jak gościa $\mathrm{z}$ tamtego świata. Zebrani tu wygnańcy między którymi było jedenastu, reprezentowali ze sobą różne klasy społeczne. Lekarze, prawnicy, wojskowi, technicy, artyści, literaci, rzemieślnicy, studenci uniwersytetu i także siedemnastoletni uczniowie gimnazjalni ${ }^{35}$.

W Krasnojarsku Bohdanowicz spędził pięć dni. W tym czasie, jak wspominał, mógł uczestniczyć w bujnym życiu zarówno politycznym, jak i umysłowym więźniów, którzy, co jest zastanawiające, posiadali w swojej dyspozycji zakazane książki, instrumenty muzyczne, a nawet przyrządy malarskie. To w więzieniu krasnojarskim Bohdanowicz miał jakoby sposobność zapoznać się z paryskim wydaniem czwartego tomu Dziet Mickiewicza, czytając m.in. Księgi Narodu polskiego i pielgrzymstwa polskiego, oraz czwartą część Dziadów ${ }^{36}$.

Z więzienia krasnojarskiego Bohdanowicz rozpoczął kolejny etap swojej podróży do Kary. Tym razem przystankiem na trasie do ostatecznego miejsca zesłania była stolica Syberii Wschodniej - Irkuck. Opisując etap podróży z Krasnojarska do Irkucka zanotował m.in.:

Po tym gościńcu bez względu na możebne zmiany klimatyczne snują się każdotygodniowo jak rok długi z akuratnością pociągów kolei żelaznych, posępne zastępy aresztantów, oznajmiając mieszkańcom swój pochód głuchym brzękiem łańcuchów ${ }^{37}$.

Jakże analogiczne pod tym względem były spostrzeżenia Wacława Sieroszewskiego, który odnosząc się do podobnych epizodów z podróży zesłańców, wspierając się przy tym własnymi doświadczeniami, w pierwszym zdaniu powieści Łańcuchy pisał:

Z pośród dźwięków posępnych i przejmujących dla rodzaju ludzkiego wszędzie i po wsze czasy - dźwięk łańcuchów rozbrzmiewa szczególnie żałośnie dla ucha polskiego. Toteż słysząc go, obracali się ludziska, zatrzymywali najbardziej spieszący przechodnie, aby rzucić smutnym spojrzeniem gromadę ludzi, idących kolumną ${ }^{38}$.

W świetle wspomnień Bohdanowicza kilkusetosobowa grupa zesłańców większość wędrówki z Krasnojarska do Irkucka, pokonała na jednokonnych kibitkach w asyście pieszo postępujących obok żołnierzy-strażników. Na pokonanie tego

35 Российский государственный исторический архив, Фонд 1903, опис 1, дело 3, л. 118.

36 Informacja ta budzi pewne wątpliwości. Czwarty tom „Dzieł” Mickiewicza, zawierający m. in. „Księgi Narodu polskiego i pielgrzymstwa polskiego”, został wydany nakładem Księgarni Luksemburskiej w Paryżu w 1880 r. a więc kilka miesięcy później niż Bohdanowicz przybył do Krasnojarska.

${ }^{37}$ F. Bohdanowicz, Wspomnienia więźnia..., s. 171.

38 W. Sieroszewski, Pisma, t. 14, Łańcuchy. Powieść, Warszawa 1926, s. 3. 
odcinka drogi liczącego zdaniem Bohdanowicza 1006 wiorst ${ }^{39}$ zesłańcy potrzebowali 62 dni, a dzienna marszruta wynosiła od 40 do 50 wiorst. Zazwyczaj po dwóch lub trzech dniach marszu następował jednodniowy odpoczynek na stacjach etapowych. Z podróży tej Bohdanowiczowi zapadła w pamięci szczególnie postać niejakiego Szemiota ${ }^{40}$ - siedemdziesięcioletniego starca, z którym Bohdanowicz dzielił miejsce na odcinku z Krasnojarska do Kańska, liczącego 248 wiorst. Szemiot z zamiłowania, a zapewne i z wykształcenia geolog, podróż na Syberię odbywał po raz trzeci, gdyż wcześniej dwukrotnie był skazywany za przestępstwa polityczne na zesłanie, na którym swego czasu sprawował nawet w guberni jenisejskiej nadzór nad pracami górniczymi. W świetle wspomnień Bohdanowicza

ten starzec mimo tak podeszłego wieku nosił się z pomysłami istotnie młodzieńczymi [...] a obecnie szedł na wygnanie po raz trzeci wraz z synami, córką i zięciem, nie troszcząc się bynajmniej zarówno swą własną, jako też dzieci swych dolą. [...] W każdym mijanym przez nas pagórku widział skarby złóż złota [...] kamieniami i żwirem napełniał woreczki - i tym sposobem przedłużał naszą podróż $\dot{z}^{41}$.

Poza pasją geologiczną Szemiot miał też i drugą słabość. Była nią potrzeba nieustannego szerzenia wśród więźniów kryminalnych propagandy rewolucyjnej. Przy każdej nadarzającej się okazji

występował przed gromadzącą się na postojach rzeszą zesłańców z długą oracją, kończącą się trzema nieustannie powtarzającymi się pytaniami. Pierwsze z nich brzmiało: »Kto was skazał na wygnanie i zatratę?« - Chór zesłańców odpowiadał: »Car«. Drugie pytanie brzmiało: »Kto wydarł wam i waszej braci ziemię, kto obarcza ich podatkami, kto rabuje ostatni ich dobytek?« - Chór odpowiadał: »Car«. Trzecie pytanie brzmiało: »Kto was stworzonych do cieszenia się wolnością przemienia w swych niewolników?«. Chór odpowiadał: »Car«. Z każdej takiej misji sędziwy ów starzec - pisał Bohdanowicz - powracał do swego towarzystwa promienny silną wiarą, że ziarno propagandy rewolucyjnej zaszczepione głęboko w serca i dusze aresztanckiej rzeszy obfite wkrótce wyda plony ${ }^{42}$.

W Kańsku Bohdanowicz pożegnał się z Szemiotem, jego synami oraz innymi zesłańcami, którzy na mocy wyroku skazani zostali na osiedlenie w tym miasteczku. W partii politycznych zesłańców pozostało już tylko sześć osób, z których cztery skazane były na ciężkie roboty (Bohdanowicz, Bogrynowski, Priedtieczyński, Owczynnikow), zaś pozostałe dwie: studenci Czeczkowski i Margolin - na osiedlenie w guberni irkuckiej. Ostatni etap podróży do Irkucka był szczegól-

${ }^{39}$ Potwierdza to w swoich wspomnieniach Józef Białynia Chołodecki, który notował, że droga z Krasnojarska do Irkucka liczyła dokładnie 1008 wiorst. Zob. J. Białynia Chołodecki, Pamiętnik Powstania styczniowego. W pięćdziesiąta rocznice wypadków, Lwów 1913, s. 92-93.

${ }^{40} \mathrm{O}$ nieznanym z imienia Szemiocie nie udało się nic bliższego ustalić.

${ }^{41}$ Российский государственный архив социально-политической истории, Фонд 70, опис 50, дело 67, л. 163.

${ }^{42}$ Tamże, л. 163-164. 
nie uciążliwy ze względu na pojawiające się mrozy dochodzące do 20 stopni oraz śnieżyce. Jak wspominał Bohdanowicz, w domach etapowych było okrutnie zimno, szerzyło się robactwo, dokuczał niedostatek strawy, a prócz tego zesłańcy spotykali się z dodatkowymi nieprzyjemnościami ze strony pijanych, gburowatych oficerów i ich podkomendnych, często przetrzymujących więźniów na mrozie. Sam Bohdanowicz na własnej skórze odczuł brutalność postępowania strażników, którzy m.in. potwierdzając jego tożsamość, wkładali mu do ust świeczkę, aby sprawdzić, czy jego stan uzębienia zgadza się z zamieszczonym w dokumentacji opisem ${ }^{43}$.

Późnym wieczorem 7 grudnia 1879 r. po przeprawieniu się promem przez Angarę Bohdanowicz wraz z pozostałymi zesłańcami został przekazany władzom irkuckiego więzienia.

$\mathrm{Tu}$ - zanotował, zrewidowano nas do ostatniej nitki i odprowadzono do pustej zimnej celi odmawiając nam nie tylko strawy, ale nadto ognia i wody. [...] Spaliśmy jak zabici. [...] Nowe partie więźniów przybywały tu co kilka dni, tak że grono nasze wkrótce liczyło ponad stu więźniów. W tym czasie grasujący w więzieniu irkuckim tyfus nie zapomniał i o naszej osadzie ${ }^{44}$.

Podczas pobytu w więzieniu irkuckim Bohdanowicz zaangażował się w organizację zbiorowej - słabo znanej w literaturze przedmiotu ucieczki więźniów ${ }^{45}$. Warto w tym miejscu wspomnieć, że jedyna większa wzmianka o ucieczce z więzienia w Irkucku autorstwa Elżbiety Kaczyńskiej i Bolesława Szostakowicza zawiera wiele nieścisłości i błędów. Autorzy nie wykorzystali bowiem bezpośredniego źródła - jakim były wspomnienia Bohdanowicza. Zawarta w pracy E. Kaczyńskiej lakoniczna wzmianka o ucieczce, zawierająca kardynalne błędy, wymaga sprostowania i uzupełnienia. Jak pisze Kaczyńska

w 1877 r. podkop w irkuckim »tiuremnom zamkie« zrobił polski narodnik, chemik Florian Bohdanowicz, on i siedmiu innych więźniów w dwóch grupach opuściło więzienie. Jena grupa została schwytana, drugiej udało się uciec ${ }^{46}$.

${ }^{43}$ F. Bohdanowicz, Wspomnienia więźnia..., s. 175-176.

${ }^{44}$ Российский государственный архив социально-политической истории, Фонд 70, опис 50, дело 67, л. 117-119.

${ }^{45}$ Nic o tej ucieczce, jak też o samym Bohdanowiczu, nie wspomina także Wiktoria Śliwowska w swojej pracy Ucieczki z Sybiru, Warszawa 2005.

${ }^{46}$ E. Kaczyńska, Syberia: największe więzienie świata, Warszawa 1991, s. 262. Autorka wspierała się także lakoniczną wzmianka o tym wydarzeniu podaną przez Bolesława Szostakowicza. Zob. Б. Шостакович, Поляки - политические ссыльные кониа 70-x - начала 90-х годов XIX века в Сибири, [w:] Ссыльные революиионеры в Сибири (ХІХ в. - февр. 1917 г.), Irkutsk 1973, wyp. 1, s. $67-68,95$. 
W rzeczywistości sprawa wyglądała nieco inaczej.

Ucieczka z więzienia irkuckiego, którą dokonano w lutym 1880 r., stała się możliwa dzięki pozyskaniu od żołnierzy-strażników noża kuchennego, który przez więźniów-ślusarzy został przerobiony na piłę. Posłużyła ona do przepiłowania podłogi w więziennej celi, pod którą przy pomocy gorącej wody wykopano w zmarzlinie podziemny korytarz, prowadzący do sąsiadującej z celą więziennej spiżarni. $Z$ tego miejsca już stosunkowo łatwo można było przedostać się drzwiami do biura zarządcy więzienia, stąd na dziedziniec wewnętrzny więzienia, a następnie na ulicę miasta. Do ucieczki niezbędne było zdobycie odzieży cywilnej oraz mundurów urzędniczych i żołnierskich. Ubrania cywilne dla uciekinierów pozyskano od więźniów skazanych na przesiedlenie, którym, w przeciwieństwie do przestępców kryminalnych i politycznych, zezwalano na posiadanie odzieży osobistej. Mundury żołnierskie, strój urzędniczy oraz czapki uszyto natomiast, wykorzystując na ten cel $\mathrm{m}$. in. czerwone powłoczki na poduszki, z których wykonano charakterystyczne dla mundurów czerwone wyłogi. Wystrugane natomiast $z$ drewna guziki do mundurów obłożono cynowym papierem, w jaki pakowana była herbata. Dla potrzeb jednego z uciekinierów specjalnie uszyty został strój kobiecy.

Wypiłowany w podłodze otwór, zatykany dopasowanymi deskami, prowadzący do podziemnego wykopu znajdował się pod łóźkiem Bohdanowicza. Planowaną na kilka dni akcję systematycznych ucieczek rozpoczęto 6 lutego, kiedy to sześciu więźniów, to jest przebrany w mundur urzędniczy student Popko prowadzący pod rękę przebranego za kobietę kolegę Fomiczowa, wraz z podążającym za nimi w charakterze służącego majtkiem floty czarnomorskiej Bereźniukiem odzianym w mundur żołnierski i trzymającym w ręku kosz, jak też student Wołoszenko, Jacewicz i ślusarz-mechanik, przy oddawanych na szyldwachu salutach strażników więziennych wyszli jako pierwsi na wolność. Dwa dni później 8 lutego, w ten sam sposób z więzienia wydostali się student Pozen oraz oficer marynarki Kałużyn. Następnego dnia przypadała kolej na ucieczkę Bohdanowicza i Bogranowskiego. Niestety na przeszkodzie stanął wydany tego samego dnia przez władze więzienne rozkaz wymarszu partii zesłańców do Kary. Przy rozdzielaniu więźniom kożuchów (półszubek) na drogę zorientowano się szybko o braku kilku osób ${ }^{47}$.

Wszczęte poszukiwania, rewizje i śledztwo ujawniły fakt ucieczki, co uniemożliwiło jej kontynuację. Bohdanowicza ominęły jednak dodatkowe represje, gdyż następnego dnia, zgodnie z zarządzeniem władz więziennych, rozpoczął się wymarsz grupy trzydziestu kilku więźniów, w tym 25 skazanych na ciężkie roboty. Tym samym nastąpił ostatni etap podróży wiodącej z Irkucka do miej-

47 Российский государственный архив социально-политической истории, Фонд 70, опис 50, дело 67, л. 122-126. 
sca przeznaczenia, jakim były kopalnie złota nad rzeką Karą. Końcowy, liczący blisko 1500 wiorst odcinek, Bohdanowicz pokonał w ciągu miesiąca, głównie na saniach, przemierzając wzdłuż skuty lodem Bajkał, zaśnieżone drogi i zamarznięte rzeki. W trakcie podróży skazany był na pomoc towarzyszy niedoli, gdyż stracił wzrok, który odzyskał dopiero w więzieniu karyjskim. Tu w połowie marca 1880 r. zakończyła się trwająca blisko osiem miesięcy podróż do miejsca zesłania.

Drogę z Kijowa do Kary Bohdanowicz odbył posługując się głównie trzema środkami transportu. Prawie jedną trzecią drogi przemierzył koleją żelazną, trasę o podobnej długości odbył szlakiem wodnym i niewiele większy odcinek traktem lądowym. Porównywalne odcinki pokonywał jednak w różnych warunkach bytowych, atmosferycznych, z różną prędkością i w różnym czasie. Najdogodniej, najszybciej i zarazem najkrócej trwała rozpoczęta latem podróż koleją. Znacznie dłuższe i bardziej uciążliwe były przypadające na jesienne miesiące przeprawy rzekami. Nie mniej uciążliwą i z pewnością najdłużej trwającą była kontynuowana zimą podróż pieszo i na kibitkach. Nie mniej uciążliwe od podróży były trwające od kilku do kilkunastu dni postoje w różnie dostosowanych i odmiennie zarządzanych więzieniach etapowych.

Utrwalony przez Bohdanowicza obraz podróży na Syberię wykazuje duże podobieństwo do peregrynacji Wacława Sieroszewskiego, który aresztowany w 1878 r. za udział w ruchu socjalistycznym i osadzony w X Pawilonie Cytadeli Warszawskiej, został w lipcu 1879 r., a więc w tym samym miesiącu co Bohdanowicz, skazany na zesłanie na 9 lat katorgi. Podobnie też jak Bohdanowicz po kilku miesiącach podróży dotarł na początku 1880 r. do miejsce zesłania, tj. do Wierchojańska. W cytowanej już powieści Łańcuchy, napisanej w 1919 r. w oparciu o własne doświadczenia i przeżycia, Sieroszewski przybliżył niemal identyczną z Bohdanowiczem, przynajmniej począwszy od Moskwy, podróż na Syberię głównego bohatera - Gaworka ${ }^{48}$. Co ciekawe, bohater powieści, podobnie jak Bohdanowicz, po przybyciu do więzienia w Irkucku podejmuje poprzez podkop analogiczną próbę ucieczki ${ }^{49}$. Mieszające się, a w wielu miejscach uzupełniające epizody wspomnień Floriana Bohdanowicza i literackich opisów Wacława Sieroszewskiego podkreślają wartość i rangę materiału memuarystycznego dla badań losów i peregrynacji polskich zesłańców drugiej połowy XIX w.

48 Zob. W. Sieroszewski, Pisma, t. 14, Eańcuchy. Powieść, Warszawa 1926, s. 23, 31, 42-45, 61, 70, 82, 83, 93, 118, 137, 187, 241, 284, 294, 302-304; 340.

49 Tamże, s. 376-383. 


\section{Stanisław Wiech}

\section{A TRIP TO SIBERIA ACCORDING TO FLORIAN BOHDANOWICZ'S MEMORIES}

Clorian Bohdanowicz is a translator of Georg Kennan's book "Siberia”, which has been banned many times in Russia. He was sentenced for five years of exile to Siberia in 1879 for belonging to revolutionary organizations by the Military Court in Kiev. His journey through Siberia to the destination, that is, the gold mine on the river Kara, lasted nearly eight months. The journey, which he traveled successively: by rail (summer), steamboat (autumn), on foot and kibitki (in winter), in an extremely interesting way, he described in little-known memories. According to Bogdanowicz's memoirs, the hardest parts of the prisoners' journey to Siberia were the steamer cruise and their stay in prisons (in Kiev, Mcensk, Tyumen, Krasnoyarsk and Irkutsk).

Słowa kluczowe: Florian Bohdanowicz, wspomnienia, Syberia, XIX wiek

Keywords: Florian Bohdanowicz, memories, Siberia, XIX ${ }^{\text {th }}$ century

\section{BIBLIOGRAFIA}

\section{Opracowania:}

Богданович Ф., Воспоминания узника (1876-1885), Российский государственный архив социально-политической истории, Фонд 70, опис 50, дело 67.

Богданович Ф., Воспоминания узника (1876-1885), Российский государственный исторический архив, Фонд 1903, опис 1, дело 3.

Деятели революиионного движения в России. Био-библиографическии словарь от предшественников декабристов до падении изаризма, red. Ф. Кон, А.А. Шилов Б.П. Козьмин, В.И. Невский, т. 2, Семидесятые годы, вып. 1, Москва 1929.

„Народная воля” 1879, nr 1.

Шостакович Б., Поляки - политические ссыльнье конца 70-х - начала 90-х годов ХІХ века в Сибири, [w:] Ссыльные революичонеры в Сибири (ХІХ в. - февр. 1917 г.), Иркутск 1973.

Bibliografia Polska XIX wieku, pod red. K. Estreichera, t. 2, wyd. 2, Kraków 1961.

Bohdanowicz F., Wspomnienia więźnia (1876-1885), Lwów 1888.

Kaczyńska E., Syberia: największe więzienie świata, Warszawa 1991.

Kennan G. Syberia, Lwów 1890, 1891, 1895, 1896.

Sieroszewski W., Pisma, t. 14, Łańcuchy. Powieść, Warszawa 1926.

Sytuacja polityczna Królestwa Polskiego w świetle tajnych raportów naczelników Warszawskiego Okręgu Żandarmerii z lata 1867-1872 i 1878, oprac. S. Wiech, W. Caban, Kielce 1999. 